\title{
Fractional flow reserve guided renal artery angioplasty - a new method of optimal patient selection?
}

Angioplastyka tętnicy nerkowej pod kontrolą cząstkowej rezerwy przepływu - metoda optymalnego doboru pacjentów do zabiegu rewaskularyzacji?

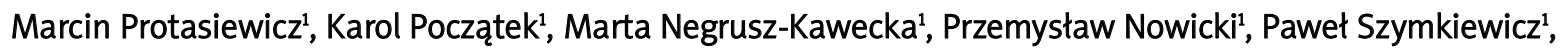 Joanna Słonina ${ }^{2}$, Arkadiusz Derkacz ${ }^{3}$, Maciej Podgórski³, Andrzej Mysiak ${ }^{1}$}

1Department and Clinic of Cardiology, Wroclaw Medical University, Poland

2Department of Radiology, Wroclaw Medical University, Poland

${ }^{3}$ Department and Clinic of Internal and Occupational Diseases and Hypertension, Wroclaw Medical University, Poland

\begin{abstract}
Randomised trials show that renal artery angioplasty based on angiographic qualification is not beneficial in improving blood pressure, renal function or mortality. At the same time, recent studies have indicated that trans-lesional pressure gradient measurement might help to identify patients in whom percutaneous renal revascularisation would have a favourable effect in terms of hypertension improvement. We present a case of a 53-year-old woman with unilateral renal artery stenosis and resistant hypertension in whom successful fractional flow reserve guided renal artery stenting was performed.
\end{abstract}

Key words: renal angioplasty, fractional flow reserve, hyperaemia, hypertension

\section{Streszczenie}

Przeprowadzone badania kliniczne z randomizacją wykazały, że kwalifikacja do zabiegu angioplastyki tętnicy nerkowej na podstawie angiograficznej oceny istotności zwężenia nie przynosi poprawy w rokowaniu pacjentów, kontroli nadciśnienia tętniczego czy funkcji wydalniczej nerek. Ostatnio pojawiły się doniesienia, że ocena gradientu ciśnień powodowanego zwężeniem tętnicy nerkowej może być pomocna w identyfikacji pacjentów odnoszących korzyść (w postaci lepszej kontroli ciśnienia tętniczego) z zabiegu przezskórnej rewaskularyzacji. Prezentujemy przypadek 53-letniej pacjentki z jednostronnym zwężeniem tętnicy nerkowej i opornym nadciśnieniem tętniczym, u której przeprowadzono długookresowo skuteczny zabieg angioplastyki tętnicy nerkowej pod kontrolą cząstkowej rezerwy przepływu.

Słowa kluczowe: angioplastyka tętnicy nerkowej, cząstkowa rezerwa przepływu, hiperemia, nadciśnienie tętnicze

\section{Introduction}

Angiography is a recognised method of diagnosing renal artery stenosis despite its significant technical limitations. The most important weakness regards the lack of precision in exact, three-dimensional imagining of topography and anatomical characteristics of renal arteries. In consequence both over- and underestimation of the stenosis grade may occur [1]. Furthermore, the angiograph does not provide enough information about the impact of the atheromatous plaque on renal perfusion: a stenosis recognized as unimportant may in fact be a causal factor in hypoperfusion of the organ with all its clinical consequences.

The functional method we applied to estimate the grade of stenosis (fractional flow reserve, FFR) allows one to determine the impact of atheromatous plaque on renal perfusion and the haemodynamic importance of stenosis. As a result, the aforementioned method might become a helpful tool in patient qualification for interventional treatment. We also believe that a more complex approach may be of interest in thorough understanding of the specific issue of stenosis in renal arteries.

\section{Corresponding autor/Adres do korespondencji:}

Marcin Protasiewicz MD, PhD, Department and Clinic of Cardiology, Wroclaw Medical University, 4 Pasteura, 50-367 Wrocław, Poland, tel.: +48 7178426 11, fax: +48 7132709 61, e-mail: mprot@poczta.onet.pl

Praca wptynęła: 27.01.2011, przyjęta do druku: 11.08.2011. 


\section{Case report}

We describe a case of a 53-year-old woman who had been treated with hypertensive treatment for 5 years. An application of combined therapy (amlodipine $10 \mathrm{mg}$, indapamide $1.5 \mathrm{mg}$ and quinapril $20 \mathrm{mg}$ ) was insufficient and resulted in recurrent incidents of increased blood pressure (up to $230 / 135 \mathrm{mmHg}$ ) with circadian level of blood pressure fluctuating between 150/90 $\mathrm{mmHg}$ and 160/95 $\mathrm{mmHg}$. Six months before admission to our hospital the patient was hospitalized on the grounds of hypertensive crisis with pulmonary oedema.

The laboratory tests done on admission showed no abnormalities. The echocardiography revealed features of preserved systolic function of the left ventricle (ejection fraction $60 \%$ ) with its diastolic dysfunction of impaired relaxation type. In the abdominal ultrasound we found the size of both kidneys to be within the normal range. Ultrasound with the duplex scan technique showed acceleration of the telediastolic flow in the left renal artery (up to $160 \mathrm{~cm} / \mathrm{s}$ ) and renal-aortic ratio (RAR) equalled 3.6. As the course of the hypertension suggested a possibility of secondary hypertension, the patient was scheduled for an aortonephrography that revealed an angiographically borderline case of $60-70 \%$ stenosis in the left renal artery outlet (fig. 1). To address the "clinical dilemma" of the optimal therapy for our patient, a functional evaluation of the pressure gradient through the stenosis was carried out. Using the guidewire-mounted pressure sensor PressureWire 5 (RADI, Sweden) a measurement of the blood pressure gradient through the stenosis was made; the difference of the mean and systolic pressure was $40 \mathrm{mmHg}$ and $19 \mathrm{mmHg}$ respectively (fig. 2). Using the same method, the relation of the blood pressure following the stenosis $\left(P_{d}\right)$ and the pressure in the aorta was estimated, resulting in a $\mathrm{P}_{d} / \mathrm{P}_{\mathrm{a}}$ ratio $=0.84$. The measurements were repeated after an injection of dopamine $(50 \mu \mathrm{g} / \mathrm{kg})$, which modifies the resistance of the renal blood vessel system, into the renal artery. A difference in the blood flow parameters was noticeable; the distinction of the mean and systolic blood pressure rose to $87 \mathrm{mmHg}$ and $46 \mathrm{mmHg}$ respectively and the $P_{d} / P_{a}$ ratio plummeted to 0.60 (fig. 3). The stenosis, therefore, was found to be haemodynamically important and we decided to perform percutaneous dilatation of the left renal artery. After the pre-dilatation with a balloon, a $6.0 \times 19 \mathrm{~mm}$ Dynamic Renal stent (Biotronic $A G$, Germany) was implanted into the initial part of the artery and expanded with the pressure of $16 \mathrm{~atm}$. The expected result was obtained, with the correct flow in peripheral branches of the left renal artery (fig. 4). A control measurement of the $P_{d} / P_{a}$ ratio with a value of 0.95 confirmed the effectiveness of the angioplasty (fig. 5).

The patient was discharged two days after the intervention. As further therapy we prescribed perindopril $10 \mathrm{mg}$ and hydrochlorothiazide $12.5 \mathrm{mg}$. Six months after the hospitalization the ambulatory blood pressure monitoring was carried out and it showed satisfactory control of the blood pressure with the mean systolic pressure of $133 \mathrm{mmHg}$ and the diastolic $74 \mathrm{mmHg}$. During the followup examination the excretive function of the kidneys was evaluated and it was found to remain within the normal range. The highest blood pressure in measurements taken by the patient at home never exceeded 140/80 $\mathrm{mmHg}$.

\section{Discussion}

Both technical limitations of angiography as well as frequently complicated clinical profiles of the patients with renal artery stenosis render it hard to indicate a patient group which may benefit from the interventional treatment $[2,3]$. As in the case of our patient, it seems particularly difficult to decide about the necessity of interventional treatment when an angiographically moderate stenosis $(50-69 \%)$ is dealt with $[4,5]$. To date, various clinical studies of invasive treatment based on angiographic evaluation of renal artery stenosis have not shown advantages in hypertension control or renal function improvement compared to pharmacological treatment [6].

Limitations of other imaging techniques such as ultrasound or CT angiography justify the search for new methods that would enable us to estimate the grade of stenosis precisely and to conclude about its impact on the renal blood flow. For many years, traditional angiographic catheters were used to measure the gradient through the stenosis. This technique also involves a concept of proportional decrease of the pressure in relation to the grade of stenosis. Because of a relatively large catheter diameter (approximately $2 \mathrm{~mm}$ ), the described method carries

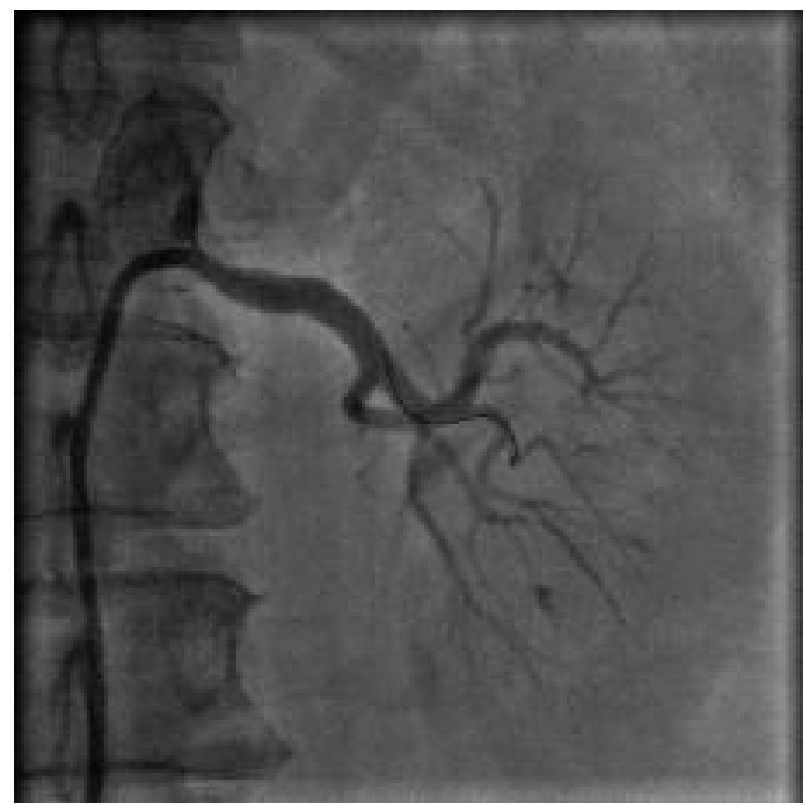

Fig. 1. Angiographic visualization of the left renal artery atherosclerotic stenosis

Ryc. 1. Obraz angiograficzny zwężenia miażdżycowego lewej tętnicy nerkowej 


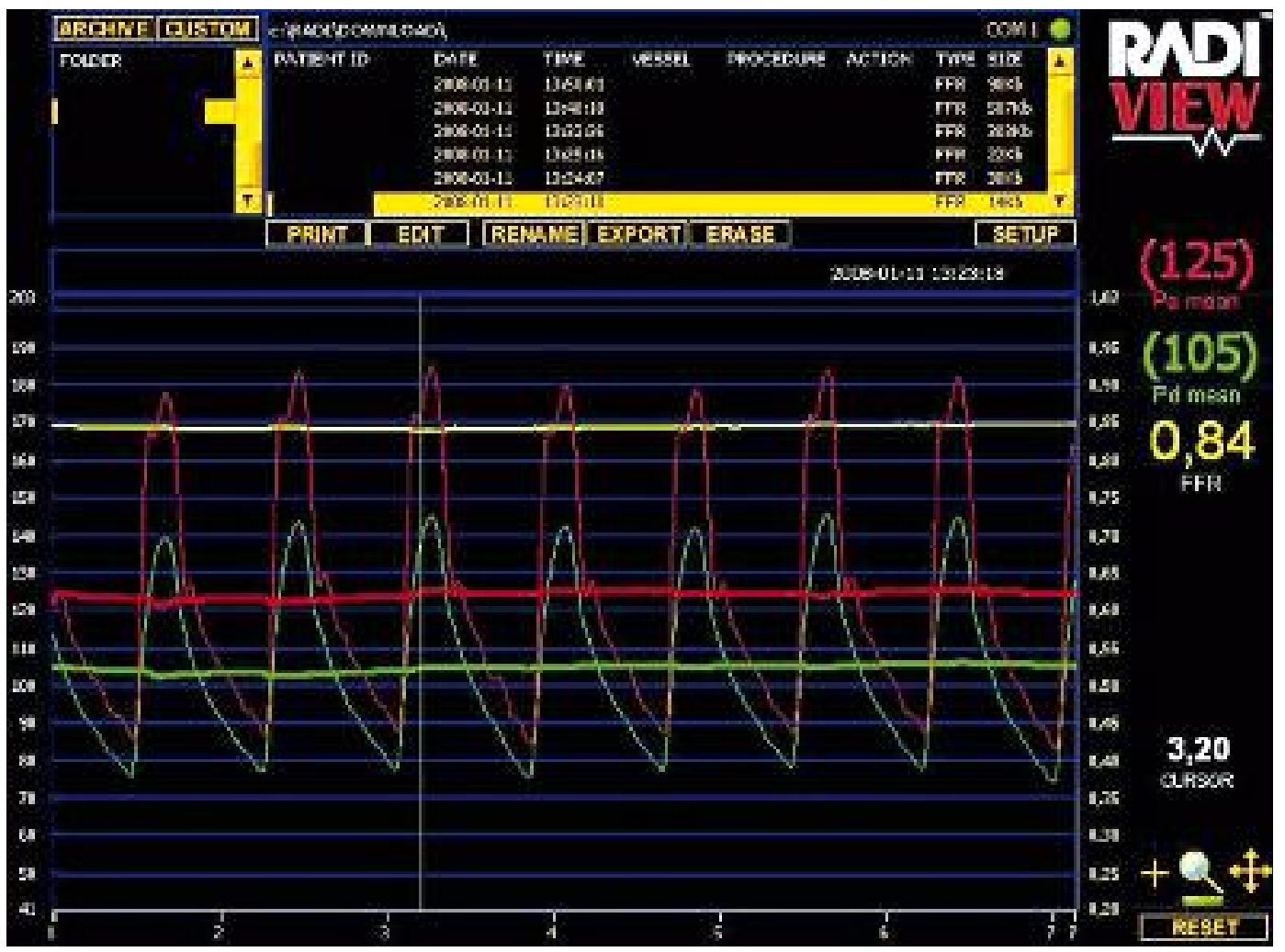

Fig. 2. Baseline pressure gradient in the left renal artery

Ryc. 2. Zapis wyjściowego gradientu ciśnień w lewej tętnicy nerkowej

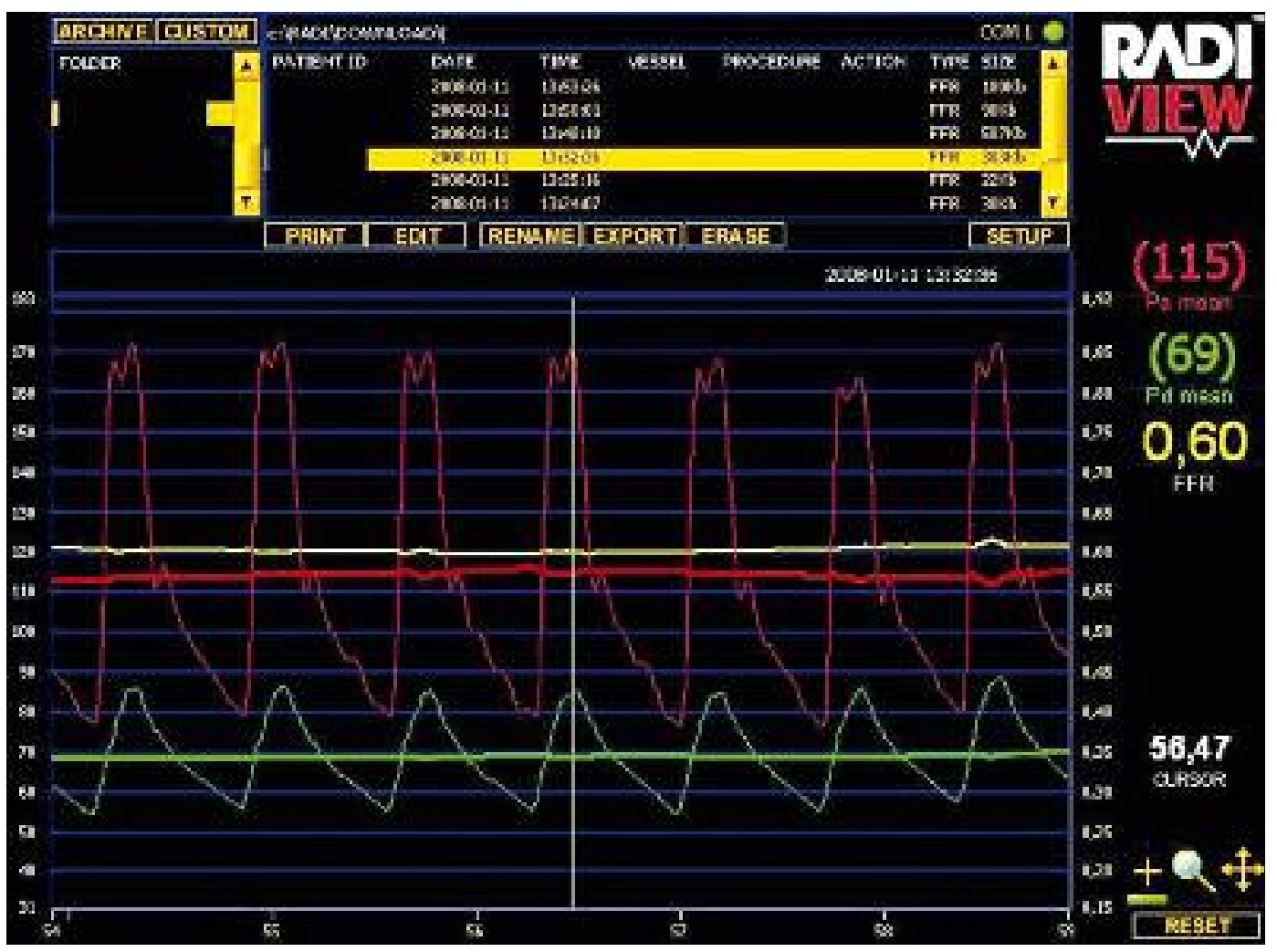

Fig. 3. Significant pressure gradient after dopamine induced hyperaemia $\left(P_{d} / P_{a}=0.60\right)$

Ryc. 3. Istotny wzrost gradientu ciśnień $w$ trakcie hiperemii wywotanej dopamina $\left(P_{d} / P_{a}=0,60\right)$ 
a risk of damaging the structure of the atheromatous plaque. Furthermore, it frequently overestimates the gradient because of the wedge of the catheter in the stenosis [7]. The method used to treat our patient, using the guidewire-mounted pressure sensor PressureWire 5, almost entirely eliminates the risks and pitfalls of the aforementioned procedure. This guidewire $(0.36 \mathrm{~mm}$ in diameter) does not increase the gradient caused by the stenosis. Additionally, a pressure sensor in its final part allows us to effectively measure renal arterial pressure distally to the stenosis. According to the experts' opinions, a gradient of the systolic blood pressure over $20 \mathrm{mmHg}$ and of the mean blood pressure over $10 \mathrm{mmHg}$ impacts on the physiology of the renal blood flow and therefore is a causal factor of secondary hypertension [8].

Authors of articles about the use of the PressureWire also indicate the usefulness of the measurement of the mean blood pressure before $\left(\mathrm{P}_{\mathrm{a}}\right.$ - aortic pressure) and after $\left(P_{d}-\right.$ distal pressure $)$ the stenosis of the renal artery and of describing their relation by their ratio: $P_{d} / P_{a}$. The results of the studies of De Bruyne et al. with the described technique indicate that a $P_{d} / P_{a}$ ratio lower than 0.90 is typical for renal ischaemia, which has been confirmed with renin secretion measurement [9].

To complete the measurement of the pressure gradient, a functional test using drugs with the ability to relax the

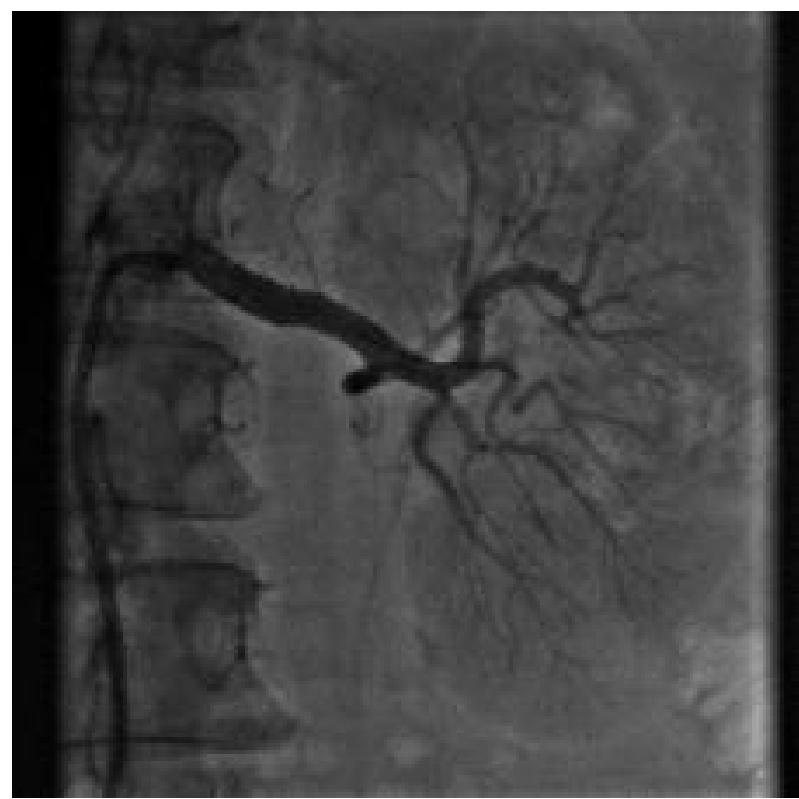

Fig. 4. Optimal result of the stent implantation Ryc. 4. Optymalny rezultat angioplastyki tętnicy nerkowej z implantacja stentu

smooth muscle tissue of renal arteries (e.g. papaverine or dopamine) can be performed. The main idea of this test is to neutralise the contraction of the efferent arteriole and

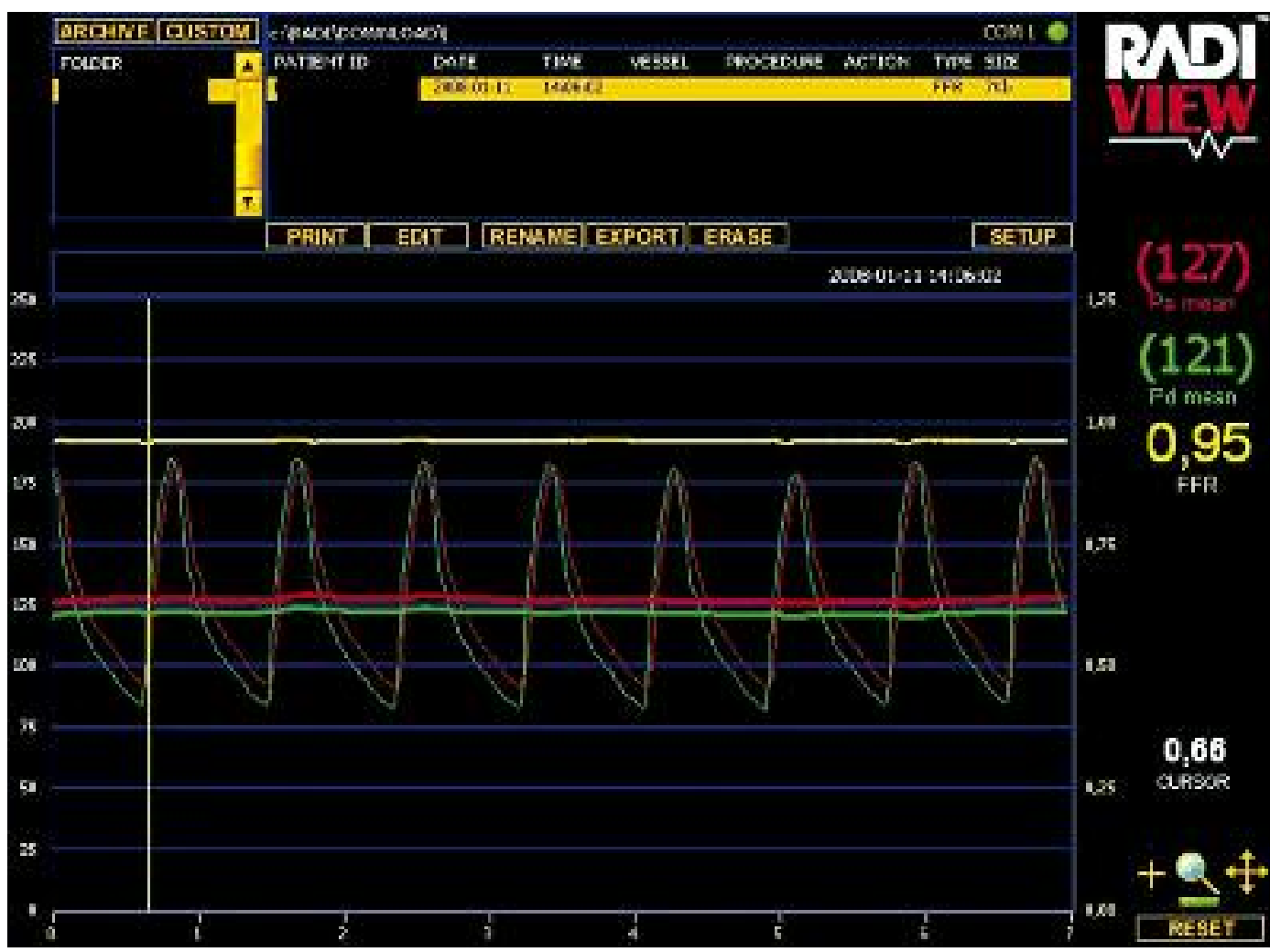

Fig. 5. Confirmation of the optimal result of stent implantation with almost complete reduction of the pressure gradient

Ryc. 5. Potwierdzenie skuteczności implantacji stentu z istotną redukcją gradientu ciśnień 
therefore to turn off the main mechanism of autoregulation in the kidney blood flow. In the case of renal artery stenosis, the necessity to maintain an effective filtration pressure provokes a contraction of the efferent arteriole and, at the same time, it lowers the gradient through the stenosis. The drop in the blood flow may cause underestimation of the gradient through the stenosis. The functional test with dilatation of efferent arterioles is supposed to reveal the genuine gradient through the stenosis. This method might be especially useful in the phase before consolidation of the pathology of the blood flow and before the structural, irreversible ischaemic changes of renal tissue appear.

If we take into consideration the fact that many authors use vasodilators to estimate the importance of renal artery stenosis, we can find that the majority of researchers consider this kind of measurement to be useful [9-12]. In recently published reports there has been growing evidence of the usefulness of fractional flow reserve (FFR) in patient qualification for percutaneous transluminal renal angioplasty (PTRA). Lasser et al. proved that a systolic pressure gradient in hyperaemia exceeding $21 \mathrm{mmHg}$ characterises a subset of patients who can possibly benefit from better control over the arterial pressure [13]. Indeed our observations confirm that positive response to renal artery angioplasty correlates with both hyperaemic systolic gradient and mean gradient [14, 15].

The presented method is applied in our institution in all borderline cases of angiographic stenosis of renal arteries. The described patient represents a typical case in which typical diagnostic methods did not provide satisfactory information of which therapeutic strategy should be favourite. The measurement with FFR showed that renal artery stenosis was impeding sufficient pharmacological control of the arterial pressure and showed that subsequent angioplasty resulted in an appreciable clinical effect in long-term observation. The accessibility and knowledge about the presented method shows great promise as in numerous cath labs the FFR equipment is becoming available. As for now we can assume that the desired clinical effect of the PTRA procedure with regard to hypotensive payoff and a beneficial effect on excretory function of the kidneys largely depends on adequate qualification of patients, particularly in cases of moderate stenosis (50-69\%). This observation seems extremely important in the light of the ASTRAL study, where no advantage of PTRA over pharmacological therapy in patients with hypertension and renal artery stenosis was evident. Of note is that the decision of PTRA in this trial was taken based on angiographic assessment despite the abovementioned limitations.

The described functional method of assessing the grade of stenosis seems to be not only a complementary tool for classical diagnostic procedures but in the near future it may become a pivotal examination in selection of an optimal treatment method. Future investigative efforts should focus on creating precise criteria which could point out patients who could fully benefit from PTRA.

\section{References}

1. Drieghe B, Madaric J, Sarno G, et al. Assessment of renal artery stenosis: side-by-side comparison of angiography and and duplex ultrasound with pressure gradient measurements Eur Heart J 2008; 29: 517-525.

2. Safian RD, Madder RD. Refining the approach to renal artery revascularization. JACC Cardiovasc Interv 2009; 2: 161-174.

3. Textor SC, Lerman L, McKusick M. The uncertain value of renal artery interventions: where are we now? JACC Cardiovasc Interv 2009; 2: 175-182.

4. White CJ. Catheter-based therapy for atherosclerotic renal artery stenosis. Circulation 2006; 113: 1464-1473.

5. Henry M, Henry I, Polydorou A, et al. Recent advances in renal artery stenting. J Cardiovasc Surg 2007; 48: 411-442.

6. Wheatley K, Ives N, Gray R, et al. Revascularization versus medical therapy for renal-artery stenosis. N Engl J Med 2009; 361: 19531962.

7. Goldstain JA, Kolluri R, Rocha-Singh K. Technical considerations for renal artery stenting. Vasc Dis Manag 2006; 3: 260-265.

8. Rundback JH, Sacks D, Kent KC, et al. Guidelines for the reporting of renal artery revascularization in clinical trials. Circulation 2002; 106: 1572.

9. De Bruyne B, Manoharan G, Pijls NH, et al. Assessment of renal artery stenosis severity by pressure gradient measurements. J Am Coll Cardiol 2006; 48: 1851-1855.

10. Manoharan G, Pijls NH, Lameire N, et al. Assessment of renal flow and flow reserve in humans. J Am Coll Cardiol 2006; 4: 620-625.

11. Subramanian R, White CJ, Rosenfield K, et al. Renal fractional flow reserve: a hemodynamic evaluation of moderate renal artery stenoses. Catheter Cardiovasc Interv 2005; 64: 480-466.

12. Jones NJ, Bates ER, Chetcuti SJ, et al. Usefulness of translesional pressure gradient and pharmacological provocation for the assessment of intermediate renal artery disease. Catheter Cardiovasc Interv 2006; 68: 429-434.

13. Lasser MA, Varma J, Shapira A, et al. Prediction of hypertension improvement after stenting of renal artery stenosis: comparative accuracy of translesional pressure gradients, intravascular ultrasound, and angiography. J Am Coll Cardiol 2009; 53: 23632371.

14. Protasiewicz M. Renal angioplasty - a big controversy? At new frontiers in invasive cardiology. Kraków 2009, Polska. http://cardio.pl/page/3075/article/169/"http://cardio.pl/page/3075/ article/169/.

15. Mangiacapra F, Trana C, Sarno G, et al. Translesional pressure gradients to predict blood pressure response after renal artery stenting in patients with renovascular hypertension. Circulation Cardiovasc Interv 2010; 3: 537-542. 